
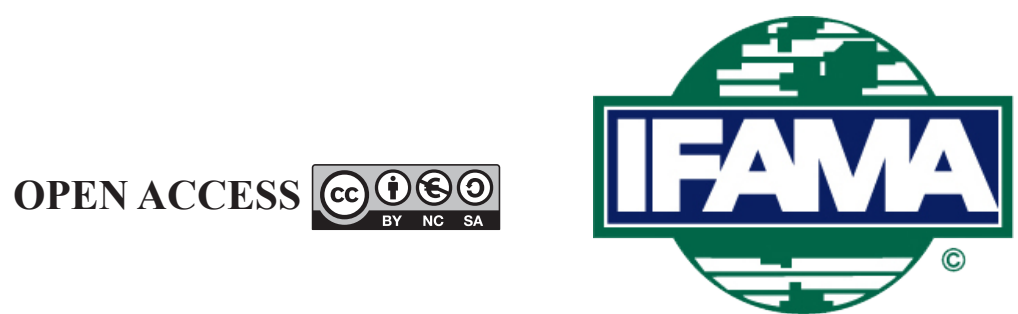

International Food and Agribusiness Management Review

Volume 23, Issue 1, 2020; DOI: 10.22434/IFAMR2019.0026

Received:17 February 2019 / Accepted: 17 September 2019

\title{
Sojagnon: shaping the Beninese soy system to meet the challenges of an emerging market
}

\author{
CASE STUDY \\ Mênouwesso Harold Hounhouigan ${ }^{\circledR a}$, Ken M.G. Kounouewa ${ }^{\mathrm{b}}$, Connetie Ayesiga ${ }^{\mathrm{c}}$ and \\ Paul T.M. Ingenbleek ${ }^{\mathrm{d}}$ \\ ${ }^{a}$ Assistant professor, School of Sciences and Techniques for Preservation and Processing of \\ Agricultural Products, National University of Agriculture, 05 BP 1752, Sakété, Benin \\ ${ }^{b} \mathrm{MSc}$, School of Economics, Socio-Anthropology and Communication for Rural Development Faculté \\ des Sciences Agronomiques, University of Abomey-Calavi, 03 BP 2819, Jéricho, Cotonou, Benin \\ ${ }^{c} P h D$ student, ${ }^{d}$ Associate professor, Marketing and Consumer Behaviour Group, \\ Wageningen University, Hollandseweg 1, 6706 KN Wageningen, the Netherlands
}

\begin{abstract}
Soybean value chains are an important means to supply the growing demand for protein in Africa and a source of income for farmers and processors. In Benin, the functioning of chains is however hindered by heterogeneous quality levels, the entrance of foreign traders, and a lack of support from the government and macro-level organizations. The local nongovernmental organization Sojagnon (the association of development of soybeans in Benin) has the mission to reorganize the Beninese soy system. It worked among others on the improvement of seed quality, the professionalization of farmers and processors, the development of a soybean value chain. In this case study, Patrice Sèwadé, Sojagnon's chairman reflects on the interventions of the past years and wonders what the next actions should be. The case highlights the role of local entrepreneurs and organizations in the rapid transformation of the African agri-food environment.
\end{abstract}

Keywords: value chain, marketing system, soybean, processors, traders JEL code: M3 1

\footnotetext{
${ }^{\circledR}$ Corresponding author: harold.hounhouigan@gmail.com
}

A teaching note has been prepared for this case study. Interested instructors at educational institutions may request the teaching note by contacting the author or IFAMA. 
'The report calls for an agricultural transformation that is more focused on a market driven, business agenda that encompasses the entire food system, not just agricultural production. It argues for an inclusive transformation based on promoting small farms and small and medium enterprises on a commercial basis with the potential to create many more productive jobs, reduce poverty, improve nutrition outcomes, and make farming and value chains more resilient to shocks from climate change, and more attractive to young workers.'

Alliance for a Green Revolution in Africa (2017)

\section{Introduction}

December 2013, Patrice Sèwadé, chairman of Sojagnon, the Association of Development of Soybean in Bénin, an NGO that brings partners together in public-private partnerships, is sitting at his office in Cotonou, the administrative capital of the Republic of Benin, West Africa. In front of him is the Regional Forum on Soybean Chain Innovations report (Alliance-Soja, 2013). As chairman of an NGO that bring parties together in public-private partnerships to foster change in the sector, the report concerns him a lot, but mostly confirms what he already knew from his experience working with soybean farmers and traders. Soybean oil producers, an important customer group of the soybean farmers, are not satisfied with the quality of soybeans available on the market.

Oil quality depends on the quality of soybeans. In return, quality of soybean depends on the seeds used by farmers; and farmers across the country use a wide variety of seeds. Oil producers are a relatively large customer group (consuming about $41 \%$ of the total production) for the small-scale soybean farmers, but soybean is also used to make products like soy-cheese, soymilk, taste enhancers like afitin (an African locust bean condiment) and infant flour. Soy-based products have the advantage to be less perishable than animalbased alternatives like meat and milk. Soybean can also be processed into flour, used to bake cakes and savory snacks (see the ad for soy pieces from Ethiopia) (Ayenan et al., 2017). This is particularly important in environments with warm ambient temperatures and where refrigerated transport and storage cannot be taken for granted. Except from oil, often produced in large factories, most soybean products are processed in small-scale businesses run by women who use traditional practices. Ideally, each application would use a different type of seed, but the main difficulty is to link the right types of soybean with the appropriate customer groups. In reality, producers are left with no choice but to use whatever is available, which is usually a mix of different varieties. This greatly affects the quality of the end-products.

The soybean system in Benin is mostly informally organized, based on oral agreements between farmers and collectors or buyers. There are only very few extension officers available to assist farmers and share production knowledge. For farmers, soybean is usually a secondary crop often produced by women with the help of their children to increase the low family income. They benefit from soybean, since it fixes nitrogen from the atmosphere to the soil, thereby enhancing fertility and the production of main crops like maize and cassava (Hailu, 2011). It's a major benefit in African farming systems, where soils have become exhausted by the need to produce more food for increasing populations, and where fertilizers are expensive and hardly available for farmers.

Additionally, soybean demand is steadily increasing due to the diversity of uses and its nutritional value (40\% proteins content (Hailu, 2011)). The latter is important to provide food for the growing population in West Africa, particularly in the urban areas. New traders have therefore entered the system, not only from Benin but also from Nigeria. A 30\% annual growth in the poultry industry from 2003 to 2008 fueled the demand for soybean meal to such an extent that an increase in imports was required. Since then, there has been a large and growing demand for soybeans which, currently, is not being met in the region. These traders care more about satisfying short-term demands, than the long-term development of the system and quality standards. They hire brokers to purchase large amounts of soybean to satisfy short-term demand and lure 
the smallholder farmers into side-selling with direct cash. The side-selling practices also reduce the impact of innovations done to improve the competitiveness within the value chain system.

As Sojagnon's core activity is to improve the marketing system for soybean through partnerships of chain actors and governmental and/or nongovernmental support organizations, Sèwadé is expected to lead the sector out of the current problematic situation. Is he doing the right things or forgetting something? More specifically, was he successful in setting up the soy supply chain? Did his actions contribute to the development of a supportive institutional environment for the chain? Did Sojagnon's actions contribute to the improvement of farm inputs? Did the proficiency of farmers and processors increase?

\section{Soy as a solution to challenges in West Africa}

The most important use of soybean worldwide, is as a raw material for animal feeds (Friedman and Brandon, 2001). In this respect, Brazil is the largest producer of soybean. Soybean production in Brazil increased from 16 million to 61 million tons from 1990 to 2007. China and EU are the world's largest soybean importers (Bindraban et al., 2009). However, the sector there has been criticized for its typical mono-cropping in which biodiversity is jeopardized to support the cultivation of one single genetically manipulated soybean type (Bindraban et al., 2009).

Soybean (Glycine max) is not an indigenous legume in Africa. The first cultivation of soybean in Africa was made by a French agronomist in 1896 in Algeria, at a government-owned botanical station (Shurtleff and Aoyagi, 2007). In 1908, the interest in soybean increased because Europe experienced a shortage of cooking oil. European settlers, particularly the UK, saw Africa as a potential production area for soybean. Soybean cultivation then spread to other African countries over the years. With recent changes taking place in West African economies, economic growth, population growth, urbanization, and upcoming middle classes, soybean is now seen as part of the solution for many challenges' corollary of growth.

During the last decade, several African countries joined the fastest growing economies in the world. For example, Ethiopia, Tanzania and Djibouti are in the top 10 of countries with the highest economic growth in 2017 while the global economy shows a trend of fragile recovery (World Bank, 2017). In spite of the small decline that economic growth in Africa experienced after the global economic trend in 2015 and 2016, Ivory Coast, Kenya, Ethiopia, Tanzania and Senegal respectively showed growth rates of 8, 6, 5.4, 7 and $6.3 \%$ (UNDESA, 2016).

One important driver of the growth is the growing population. Throughout history, labor has always been a scarce production factor in sub-Saharan Africa. With the recent population growth, this situation changes structurally. In the next twenty years, Africa's working-age population will reach 1.1 billion, which is bigger than China and India (ECA, 2017). This demographic characteristic becomes an important long-term development foundation of Africa (ECA, 2017). The population growth is expected to continue until 2100 with an estimated number of 3.4 to 4.4 billion people due to the young population, high fertility and growing life expectancy (Figure 1) (United Nations, 2015).

Africa's urbanization rate will reach 60\% in 2050, together with Asia's, accounting for $90 \%$ of world's increasing urban population since 2014 (United Nations, 2014). A relatively larger share of this population will live in cities. Some predictions state that, by 2050, the region from Abidjan to Lagos will become one big city rivalling that of Beijing by 2050 in population size (Dietz, 2016). There are four drivers behind the urbanization in Africa, namely: (1) the move to the cities within countries; (2) international migration within Africa; (3) natural demographic growth; and (4) rural towns developing into urban areas (ECA, 2017). 


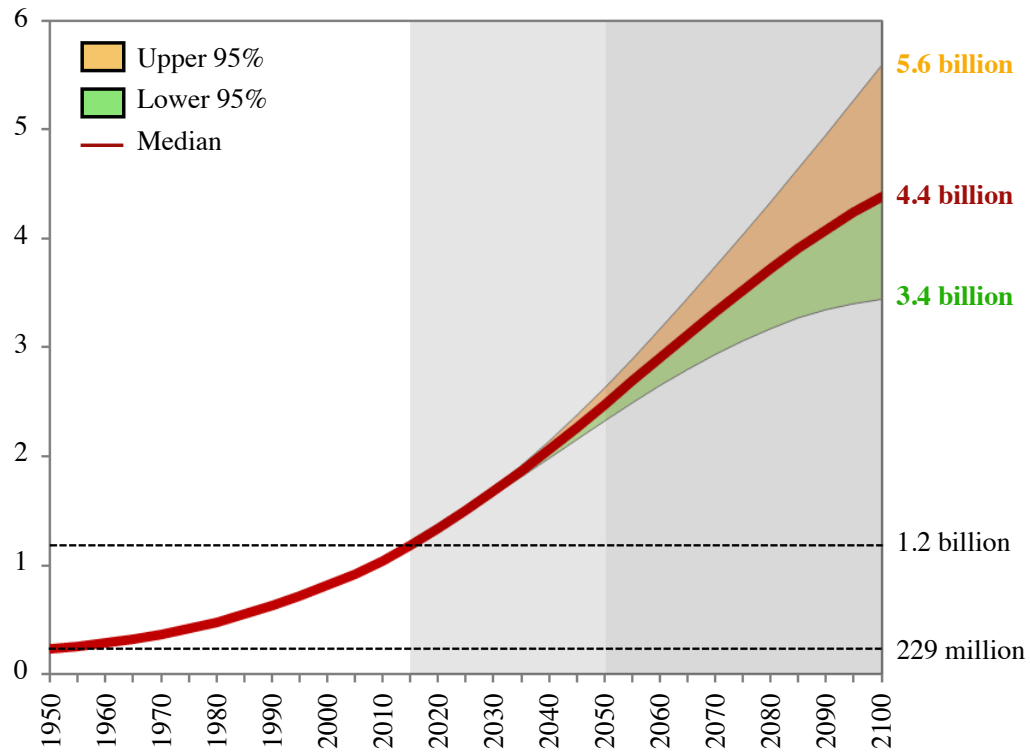

Figure 1. African population growth 1950-2100 (United Nations, 2015).

Another structural break is that, new middle classes are rising in the cities. Both in terms of percentage and absolute numbers, African middle class has grown steadily from 111 million ( $26 \%$ of the continent's population) in 1980, to 313 million (34.3\%) in 2010 (Ncube et al., 2011). The growing African middle class has different consumption patterns, consuming more western-type food and purchasing more durable goods, like cars and permanent houses (ECA, 2017). Therefore, the changing consumption trend will also create new opportunities for industry and entrepreneurs in Africa.

These new factors put pressure on the development of the food system which, in the first place, should ensure that food is available for all people, and secondly respond to the changing eating habits of the gradually richer population. African food demand is projected to double by 2050 due to increasing population, growing income, and because people no longer produce their own food, due to the rapid urbanization (AGRA, 2017). Beyond the growing demand in terms of quantity, diets are changing towards more nutritious fresh food and processed food (AGRA, 2017). Confronted to such a challenge, the Alliance for a Green Revolution in Africa, an organization established in response to a call of the former UN General Secretary Kofi Annan, calls for agricultural transformation (see the quotes at the beginning of the case).

However, food production in most African countries, is characterized by smallholder production. $80 \%$ of the 51 million African farms are smaller than 2 ha (Lowder et al., 2016). For the entire Africa, 30\% of the agricultural production is produced by farms smaller than 2 ha, and 4-20 ha farms produce another 50\% (Herrero et al., 2017). Most smallholders traditionally produce only for family consumption. Integrating them in the commercial system to meet the changing demands of the growing population is a challenge. On one hand, it requires changes in the marketing system such as different trading practices, transport, marketplaces, and price information. On the other hand, smallholders should produce the right varieties and quantities demanded by the market. To achieve this, inputs like seeds and fertilizers are required, so that supply matches demand. Sadly, farmers are not currently able to produce food at the required market standards because of the lack of inputs and the poorly organized value chain.

Chain actors and supporting organizations are increasingly gathering in public-private partnerships. These partnerships consist of governmental and/or nongovernmental organizations with an interest in the sector and expertise in rural development, former organizations as well as private-sector companies that are involved in the input and output marketing. In principle, such partnerships can remove all constraints and develop a well-functioning food supply chain because all parties are on board. 
These actions are urgent because the undernourished population in sub-Saharan Africa grew from 20.8\% in 2015 to $22.7 \%$ in 2016, and the absolute number rose from 200 million to 224 million, which now accounted for $25 \%$ of the global undernourished population (FAO, 2017). Undernourishment refers to food intake that is insufficient to meet dietary energy requirements for an active and healthy life (FAO, 2013). Besides inadequate consumption, Africa faces the challenge of nutrients supply. For example, protein supply in subSaharan Africa has been rapidly increasing since 2000, and it reached more than $230 \mathrm{~g} / \mathrm{capita}$ /day in 2010. However, it is only about half of total protein supply, compared to Iceland (Chauvin et al., 2012).

In Bénin, soy is used to combat the effects of proteins deficiency in children. But soy also has many other applications on the market. Because it is rich in protein, soy was proposed to be incorporated in flour composition for children between 6 months and 3 years (Shurleft and Aoyagi, 2009). Especially in rural areas, child health centers mix soybean flour with maize, rice and sorghum flour as a nutritional supplement for malnourished children.

\section{How soy became an important factor in Beninese economy}

The Republic of Benin in West Africa is bordered by Nigeria in the East, Togo in the West and Burkina Faso and Niger in the North. In many ways, the country is a typical African emerging market with a relatively young population ( $48.5 \%$ of the 11.18 million people is below the age of 15$)$ and a literacy rate of nearly $30 \%$, the education-level thus being relatively low.

Beninese economy is essentially based on its agriculture which provides about $32.5 \%$ of the gross domestic product and $75 \%$ of export income (FAO, 2018). When Benin became independent from colonial French power in 1960, the new republic inherited a typical mono-cropping system in the agricultural sector with cotton being the most important export crop. Although the Beninese government tries to develop other agricultural export products such as pineapple, cashew nuts, shea nuts, shrimps and cotton still accounts for more than $70 \%$ of the agricultural export value (Sodjinou et al., 2011). Diversifying the agricultural sector is an important objective of the Beninese government in order to stimulate development; especially in regions where cotton production is scarce. It can also make the economy less dependent on global cotton prices.

Unlike the systems for these crops, the marketing system for cotton is well-developed. Prices are standardized inside Benin and in line with world market prices. Farmers are organized in cooperatives which receive the necessary input materials to produce the quality standard demanded by the export market. From time to time, extension workers visit some farmers to provide them with technical knowhow. Transport is centrally organized, maintaining relatively low rates of post-harvest losses (cf. Adékambi et al., 2015).

In addition to the cotton fibers that are used for textile production, cotton plants produce seeds that can be processed into cooking oil thus forming a substitute for other plant-based oils (particularly palm oil). Cotton seed is also used as a basis for animal feed and is exported as such to Europe. As a consequence, cottonproducing smallholder farmers have two export products. It leaves them relatively well-off compared to the other farmers producing non-export or emerging export crops (Proto et al., 2000).

However, cotton is a typical agricultural commodity and its prices can fluctuate depending on supply and demand (see here for example). Therefore, a price drop might have a deep impact on the whole system. Such a price drop happened between January 2001 and May 2002, when world cotton prices fell by almost 40\%; from $\$ 0.64$ pound to $\$ 0.39$ pound (Minot and Daniels, 2005). It considerably impacted the livelihoods of cotton farmers. Many of them started to look for alternative or complementary commercial crops.

Soybean was later discovered as a suitable complement as it requires growing conditions comparable to cotton. Actually, soybean is a nitrogen-fixing legume in soil (Angie et al., 2009). It is easily integrated into cereals plantation fields. The plant is less demanding for water than corn (Javaheri and Baudoin, 2001) 
but it is particularly sensitive to water stress, as well as excessive temperatures at the time of germination, flowering, and seed growth (Dogan et al., 2007; Haskett et al., 2000).

Furthermore, soybean has a different growing season than cotton and can be grown in sequence. Therefore, soybean cultivation has been increasing since the cotton crisis in the central and the northern part of Benin, in response to the increasing demand of local traders and national industries replacing cotton seed by soybeans for oil extraction. Beninese soybean production increased from 5,000 tons in 2002 to 80,000 tons in 2012 and 99,738 tons in 2014 (INSAE, 2016) as shown in Figure 2.

The mad cow disease which took hostage of the beef production in European Union in the late 1990s is another surprising factor that contributed to the growing soybean production. People eating beef coming from contaminated cows can develop Creutzfelt-Jacob's disease, a brain disease that killed more than 200 people during the crisis. The mad cow disease can be caused by contaminated animal feed and, in response to this crisis in European animal nutrition, companies rapidly started to search for alternative feed sources. Their search also brought them to Benin: the good prices proposed to Beninese cotton grain exporters left the Beninese cotton oil industry without supplies. The seed-processing companies then turned to the Beninese government for help; they suggested shea nut, peanut, sunflower and soybean as possible substitutes.

\subsection{Setting-up a soy supply chain}

At that time M. Patrice Sèwadé was working as director of agricultural chains at Fludor SA, the largest seed oil producer in the country. Once Fludor decided to start experimenting with soybean as an alternative for cotton, it was his responsibility to organize supply. He then started encouraging farmers near the factory to grow soybean in 2006.

The first results were encouraging. Farmers still cultivated cotton as their main crop and grew some fruits and vegetables to complement the family menu. Soybean entered the farm as a complementary crop. Men were still mostly responsible for cotton as the main cash crop and many of them left the production of soy to their wives or young people. Still, the area planted with soybean was limited (on average 0.5 ha for women and between 1 and 1.5 ha for men and young people) (Sidi, 2012). Incomes generated by soybean were also smaller as the marketing system was still informal (the farm price is about $€ 0.30 / \mathrm{kg}$ today). Farmers sold their soybeans to collectors that came to visit them. The collectors transport the soy either in small cars or on motorbikes, convenient for the sometimes-bad conditions of the roads, especially in regions that are further away from the main roads. Collectors may also sell to small-scale producers of soymilk, cheese and afitin. Meanwhile, wholesalers possess large warehouses in towns and export soybeans and or supply oil factories.

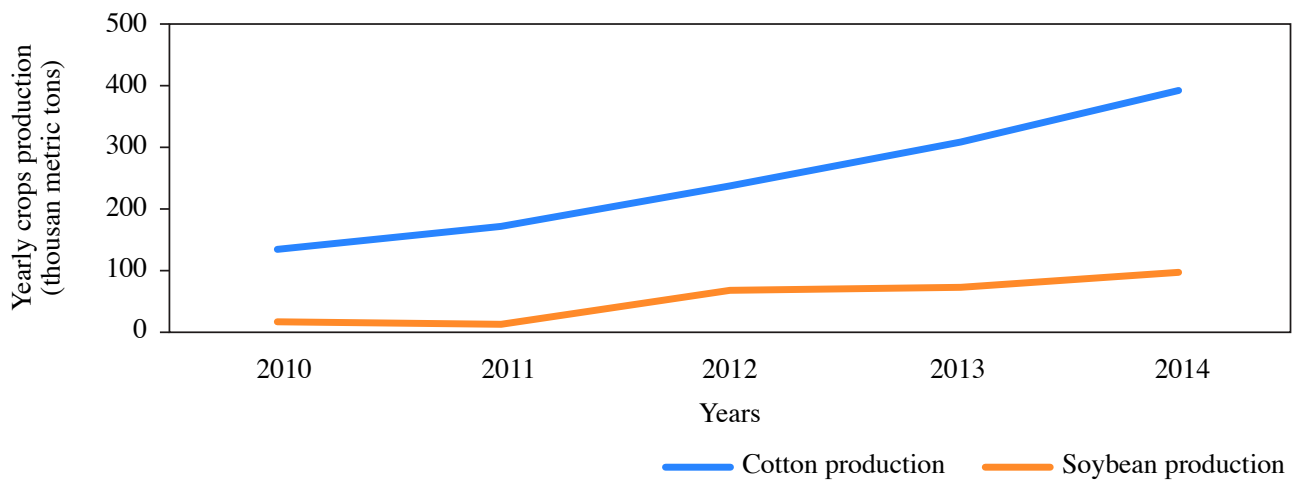

Figure 2. Cotton and soy production in Benin. (Data available at: https://fr.actualitix.com/pays/ben/beninsoja-production.php) 
Sèwadé started to invest more substantially in the new soy supply chain. He distributed seeds, encouraged and even helped farmers to restore roads and a bridge in order to enable collectors to visit remote communities. In his plan for 2009, Sèwadé proposed to group producers in cooperatives, thus creating a structure that made the bulking and marketing from farmers much easier because the soybeans could be aggregated by the farmer organizations and then transported to the factory. The farmer organizations also provided a structure through which farmers could be supplied with seeds, fertilizer, and services like financial support through micro loans and trainings on best practices for growing and harvesting soybean. His plans also involved government extension services and financial organizations, thus forming a real public-private partnership. Fludor as such assisted in the formation of 49 cooperatives in 41 municipalities across the country that were visited by 28 newly recruited extension workers.

During the first year, the company distributed almost 1,200 kg of soybean seed, much less than what it primarily targeted (100 tons). Sèwadé turned to the national agricultural research centers to supply the seeds, but they didn't have enough in stock. The Beninese Ministry of Agriculture found 4 tons in Nigeria through one of its projects, but it still wasn't enough. The government then supported Fludor with a subsidy of $€$ 91,695 to buy seed anywhere it could find supplies. The company found 100 tons in Ghana, but it couldn't import it before the planting season started, due to formalities at the border.

To address the situation, Sèwadé decided to select the seeds that were in a reasonable condition from the factory's stock. Then the company chose 23,000 producers from the 49 cooperatives it previously trained to multiply the seeds. The initial 100 tons expected finally came at the end of the year but were stored in bad conditions; it caused the loss of the major part of the seeds. At the end of the 'operation Soja 2009' 26,000 tons of soybean was produced in the country.

In the first years, the system worked relatively well. In 2014, Benin became the fifth largest soy producer in Africa with 99,738 tons, behind South Africa (948,000 tons), Nigeria (679,000 tons), Zambia (214,179 tons) and Malawi (110,000 tons) according to the FAO (2014).

\section{Development of the institutional environment}

The institutional environment around the chain started to develop too, after the value chain development. The newly formed cooperatives supplying Fludor started to join forces and created a new body that could represent their joint interests. By 2010 many farmers were convinced that growing soybean added value for their farm because they earned an additional income and have seen the impact of soybean on the fertility of their soils. In 2010 they organized a general assembly where the decision was made to establish the UNPS (National Union of Soy Producers). According to the executive director of UNPS, Mr. Fortuné Amonsou: 'the new union suffered very soon from the lack of professional leaders capable of representing farmers' interests in front of strong economic powers like oil factories and political powers like the government'. Not being able to demonstrate leadership for the sector, NGOs left the organization apart from their development projects and the members of the cooperatives didn't put much energy in their joint union.

The 'Alliance Soja', another soy organization, was formed in 2008 by several NGOs and Redad, a network for sustainable farming. The objective of the group was to promote soybean among farmers and to solve some of the supply chain problems in the north of the country. Alliance soya also suggested that farmers group themselves into cooperatives, and later the cooperatives to form a union. In 2010, the organization started functioning under the name Union Régionale des Producteurs de Soja (URPS).

The URPS soon engaged in projects with the German organization GIZ. As part of the collaboration, GIZ restructured the Union which at the time, had approximately 7,000 members. In 2015 the membership terms of the union were defined. Each soybean farmer would pay a membership fee of $€ 10$, in an equivalent of their soybean harvest. In 2017, the union had 3,120 members. 
By 2015 some members also started to breathe new life into the UNPS. The government put pressure on the organization because it wanted to introduce a new soy variety, Jengouman which is more productive than most existing varieties. Working with a union that could cover most of the cooperatives would help to harmonize production across the country by introducing the new variety on a larger scale. The UNPS was therefore reorganized in a way that gave the government more influence in the organization. A new technical team was established that could support farmers in strengthening the quality and quantity of their soybean. The organization became a member of umbrella organizations of farmer unions in Benin, namely Fupro.

Both the UNPS and URPS are involved in many projects and activities, including professionalizing farmers and sourcing inputs like seeds and fertilizer for them, introducing new practices and technologies, like the bio fertilizer inoculant which can considerably improve the productivity of soy plants (see N2Africa.org). The organizations also started to work with small soybean artisanal processors to spread risks by diversifying output markets and they helped member cooperatives to professionalize their organizations. The UNPS works on the pricing of soy to make it more transparent. Around 2016-2017, the URPS represented around 3,000 farmers; most of them located in the north of the country, and the UNPS represented approximately 7,000 farmers across the country.

The ongoing problems with the UNPS and the unwillingness of representatives of the URPS to discuss a merger, led some board members of the URPS to start a third organization, the ABS (Association Bénin Soja) in 2017. The initiative was supported by several national and international development organizations, such as the church-related development organization DEDRAS, German Development Organization GIZ, Swiss Cooperation Office cooperation as well as partners from China.

\section{The position of the farmers}

With the dynamics in the institutions surrounding the chain, interests of individual farmers were still not well taken care of. Essentially, farmers could only rely on their direct peers, the members of the cooperative in their community; but these farmers are in the same situation as their own. In absence of a well-functioning extension network, the information they receive, on things like prices and preferred soy varieties on the market, almost exclusively comes from the collectors visiting the community. Also, cases were reported in which collectors cheated in the weighing of the soybeans: when farmers checked the weight using their own scales, they observed a difference with the measurement performed by the collector.

With pressure on the availability of supplies, especially for the large customers, the factories started to engage the wholesalers to source exclusively for them and they, in turn, engaged the village collectors to source for a specific factory. This system was initially advantageous because farmers and their buyers had common interests. Farmers would for example accept the seeds that the village collectors offered them and receive advance payments from the factory. This helped them invest in input materials like fertilizer and it showed commitment from the factory. As such, an actual supply chain was getting in shape.

However, with the growing demand for soybean throughout West Africa, the pressure on the system increased and new buyers appeared on stage. To meet the growing demand of their buyers, wholesalers started searching for new supply sources and moved to different regions where they recruited brokers to establish contact with farmers. While collectors and wholesalers became the owners of the soy, brokers just arranged the transactions between a farmer or a farmer cooperative and a wholesaler. Because the demand is even higher and increasing across the Nigerian border, wholesalers from Nigeria also started to approach Beninese brokers. As the system was still lacking institutions to set prices and relay market information to farmers, farmers became easy targets to tricks played by collectors, wholesalers and brokers. Cases are known of Nigerians that crossed the border with a motorbike and money to propose farmers to exchange their soybeans against the motorbike and money. Farmers sometimes were not able to properly compare the value of the motorbike with the value of their soybeans and accepted deals that they later regretted. 
Farmers were also in trouble if they had already accepted down payments of another buyer to sell the soybean to them. Factories accused farmers of selling a part of the harvest to another buyer (and telling the initial buyer who made the down payment that harvest was small that year). Fludor, for example, had contracts with farmers stating that they would purchase the soybean for $€ 0.20 / \mathrm{kg}$ and provide farmers with an additional commission fee to cover costs for sewing bags, transport and storage of $€ 0.023 / \mathrm{kg}$, leading to an arrangement of $€ 0.21 / \mathrm{kg}$ in total. In spite of that some farmers decided to sell their harvest for $€ 0.20 / \mathrm{kg}$ in cash. This option was attractive to farmers with a direct need for cash for example to pay school fees or their contribution to ceremonies like weddings and funerals.

Fludor would respond by putting farmers on a 'blacklist' until they had compensated them for their losses. This means that in case no other collectors would show up at the community, the farmer would be stuck with her/his harvest because the collector working for Fludor refused to buy from them. The result was that perfectly fine soybeans would be stored and left unused to even perish at different places in the country. Fludor also tried to keep cooperatives and even the unions above cooperatives responsible for the losses it experienced. As a consequence, the partnership between Fludor and the Alliance Soja, meant by both parties to secure supplies/output market, ended in a failure.

In short, the soy system in Benin was characterized by a tremendous pressure on all actors. At this point, Sèwadé who was responsible for the agricultural supply chain at Fludor and for solving problems in the supply chain, made up his mind and decided to resign. Sèwadé:

'I have already worked with Fludor for 12 years, I passed all the stages. I needed to learn other things. What I was doing at the time no longer felt right. So, I talked to my boss, and told him that I wanted to leave. I didn't know how I would get a salary, but I wanted to help farmer organizations. That was my target.'

\section{6. 'Soy is good'}

At the time he left Fludor, Sèwadé first leveraged his experience in the sector as a consultant, working for the World Bank and the African Union among others. He built some experience on other agricultural sectors working on different projects, but 'my passion is really with the soy sector' as he says. In 2011 year, he established Sojagnon. Sèwadé: 'The official name of our organization is Association for development of soybean in Benin, but we simply call it Sojagnon, which means in our local language 'soy is good'.

Sojagnon is a non-governmental organization that aims to support the soybean supply chain. Sèwadé:

'In short, the vision right in front of us is: how to produce high quality soybean and link it to the markets'. In that market there are small and large enterprises at first, because they are short of soybean. Right now, in Benin we produce not more than 100,000 tons. The demand, in Benin only, is of more than 200,000 tons. Nigeria needs 600,000 tons. Also, Togo is looking for 100,000 tons. Niger, Burkina Faso and others cope with food security problems and see soy as part of the solution, but most countries produce less than they need themselves.'

The basic solutions to the problem are simple: increasing the production and strengthening the value chain. This requires knowledge and collaboration. To generate the relevant knowledge, Sojagnon works with research institutes. Sèwadé:

'Farmers and small processors have hardly any access to science-based innovation like agricultural biotechnology, genetically modified food. We therefore engage in projects with scientists on how to improve the yield, the quality of soybeans and the products that come out of it, like milk and afitin. We are working with the University of Abomey-Calavi, the National Research Institutes, and organizations from abroad like Wageningen University and IITA (International Institute for Tropical 
Agriculture). We make sure that these scientists go to the field to meet farmers and see what we are achieving. It's important that they directly witness the problems at the farm. That fosters co-creation.'

Sojagnon strengthens collaboration by establishing public-private partnerships in which research institutes are connected to farmer and/or producer organizations and other parties like government extension workers and microfinance institutions. Sojagnon now works with 44 cooperatives, representing a total of approximately 25,000 farmers. However, new groups are still added. It also works with 35 producer organizations across the country, representing 1,500 producers. Sojagnon manages these projects with a relatively small organization consisting of Sèwadé, who as coordinator runs the day-to-day management decisions and who is supported by a staff of approximately twenty people, including project managers, secretarial support and others. The organization further consists of an executive board that oversees the daily management and a committee of control to check the books.

\subsection{Processors representing the demand side}

First, as a market-driven organization, Sojagnon works at the demand-side by engaging in several projects that aim to professionalize soybean processors. While oil producers were already large industrial companies, the producers of milk, cheese and afitin are almost without exception female entrepreneurs that engage in soybean processing next to other jobs and/or running their households. Sèwadé: 'the female producers often have informal groups already, in which they share ideas and help each other. We approach them and start to work with the leaders of these groups because through them we can effectively disseminate new ideas and practices.' That way, Sojagnon already trained over 750 processors in afitin, milk and cheese production.

\subsection{Improving the quality of inputs}

Second, Sojagnon works on the improvement of seeds and propagation materials. Sèwadé:

'When we were building capacity with the processors, we learnt from them that quality of milk, cheese and afitin depends on the quality of the seed. At that point, farmers were producing seeds themselves. If they are paid a good price, they will keep the seeds of their plants for the next year. So, it's a process of self-selection, only based on price. We do not know one variety from another. If we distribute seeds, the variety is still mostly random. We can only tell differences by the color of the seed. There are even different prices charged for seeds with different colors, but no one knows what's inside. We therefore initiated a new project to find out which soybean variety fits best with a particular end-product. Scientists currently explore the different varieties grown in Benin and in the surrounding countries. These varieties will be tested on their resilience to climatic and weather conditions, their productivity and their suitability for the different products. With that knowledge, we can develop the capacity of the processors even further. We will select, maybe two or three varieties that are high yielding, and disseminate these to the farmers. Through the Agricultural Ministry, we will certify the seeds that we select and communicate to farmers why it's important to grow these.'

\subsection{Developing the value chain}

The process of improvement comes to the core of the problem which, according to Sèwadé, is the adoption of developed technologies by farmers. Although, according to Patrice Sèwadé, farmers often agree that the technologies will help them, they still don't adopt them.

'It's difficult for farmers to see the effects of the changes that they make. Much of the quality of the soybean is determined before the harvest, it depends on the seeds you use, the use of inoculant, of fertilizer, and of course how well the farm is managed. The seeds contain the agronomic properties, and that fertilizer and inoculant influence the growing process, thus affecting quality. Besides that, the harvest quality is affected by the storage facilities. If all these things go well, the market should 
still pay for the higher quality in order to make farmers experience the benefits of all their work. If a foreign trader passes by to trick the farmer in an unfavorable deal for their harvest, they don't just take the soybeans, but they also destroy our value chain including all the right practices that were just implemented.'

To create value chains, Sojagnon fulfills a mediating/facilitating role in the chain itself. On one hand, it encourages farmers to adopt certain seeds and practices so that they produce soybean that is particularly suitable for a specific purpose, and on the other hand, encourages customer groups/buyers to pay for the better quality and develop relationships with farmer organizations. Meanwhile Sojagnon prepares its own exit from the chain by explaining to producers how to provide feedback to the farmers about which types of soy they prefer, in which quantities and with which specific quality levels. By initiating the communication between farmers and processors, relationships are being formed so that the chain processes can run independently without further interventions of the Sojagnon staff.

\subsection{Professionalizing the farmers}

In order to ensure that farmers are responsive, Sojagnon works on the professionalization of the farmers. They try to make them function more like businesses that evaluate activities of the past year and set target for the next. 'It's important that there is a clear relationship between the activities they do and the money they make. This way they will create ownership for the increase of productivity and thereby develop a demand for the innovations that we can offer them.'

The first step is to ensure that information and knowledge reach the farmers. Reaching them on an individual basis is virtually impossible, so Sojagnon first ensures that farmers are organized in groups through which information can be disseminated effectively. Sèwadé:

'When we make contact, there often are already some informal farmer organizations formed on an ad-hoc basis. Such groups come and go. We therefore work with the local extension services, the leaders of the municipalities, local chiefs, or other central people in the region. They help us identify the good soybean producers. We bring them together and explain to them how to work together, why they should be in one group, and advise them to get registered. All the groups that we work with are officially registered so that their rights and duties are clear for everyone. Once the group exists, we conduct meetings with them to know their constraints and needs. Depending on the discussions we build capacity, by teaching them how to cultivate, explaining what the market wants, and telling them where they can sell their products, how to meet quality standards. So, we are not going top-down: the information needed is coming from the bottom up. We try to be responsive to that.'

To support this process Sojagnon also makes use of broadcasting organizations comparable to farm radio. Radio stations ask farmers to send SMS messages about which and how much input materials they would like to purchase, like seeds and inoculants. With such information, Sojagnon and its partners can predict the demand and prevent stock out. In addition, it has a demonstration plot of about 7 ha used to train farmers by showing the results of demonstrated practices and technologies.

\subsection{Organizing support at the macro-level}

In order to help the farmers move forward, it's almost inevitable that Sojagnon also gets involved in the political lobby. Sojagnon therefore participates in REDAD, a network that brings together a number of farmer organizations and NGOs to stimulate the development of the agricultural sector at large. However, soy sector's position itself is less favorable. To increase the quantity and quality of soybean production, it's important that all organizations effectively work with the same vision. In the strategic development plan for the agricultural sector of Beninese government, soy plays just a minor role or none at all (see here for the plan in French). Sèwadé blames the existing umbrella organizations for an ineffective lobby, saying that 
there is too much rivalry between the organizations. Sojagnon therefore took the initiative to develop one common plan for the soybean sector. Sèwadé:

'Now we are taking this plan to the government and we hope that in the next strategic plan there will be support for only one common organization. The strategic plan will take everybody into account, each person, each organization, each group, each partner that is working on soybean, must be involved. So that the vision of the strategic plan will be for the whole country. We started a lobby to convince the new government, because it's good for food security, it's good for the industry, and it's good for business.'

Without surprise, Sojagnon foresees many other coming opportunities in which it could play a role when the soy sector develops further.

\section{The next steps}

\subsection{Consumer acceptance and branding}

Firstly, soybean has not yet reached its full potential. As many consumers are still reluctant towards accepting certain soy products, some level of market development is needed by increasing awareness on the benefits of soy products and how they can be used to further increase consumption (see for example this Nigerian add on how to make your own soy milk). While Sojagnon is still stabilizing quality, it already thinks of helping producers to develop brands. A stable quality (that always meets the expectations raised by the brand name) is an essential prerequisite for a brand. Sojagnon would like to help producers to develop brands and their marketing strategies to segment the market, target different segments, and position the brands with associated instruments.

\subsection{Diversification}

Secondly, Sojagnon looks beyond soybean into related products such as Kersting's Groundnut, another legume crop related to soybean but with an even higher protein content and a strong traditional usage in some parts of Benin where it is mostly consumed at special occasions like Christmas. Sojagnon can leverage its experience from soybean to develop the chains for such products.

\subsection{Generating entrepreneurship}

Thirdly, Sojagnon started to stimulate entrepreneurship by establishing the Benin Agribusiness Incubation Hub, a platform that is registered as a limited company where entrepreneurs can meet peers and receive support from scientists for example, consultants, senior entrepreneurs and legal experts. The new organization targets processors and traders, that focus on the Beninese market and/or export to other African countries or Europe.

\subsection{Digitalizing the chain}

Fourthly, Sojagnon and its partners brainstorm on how ICT can further improve the chain, such as systems to inform farmers about demanded qualities and varieties, about treatment of crop diseases, about market prices, etc. Similar systems are already implemented in other countries like e-Choupal in India. If such systems would be extended with an option that allows farmers to send information back to the system, then farm data can also be incorporated in data systems on which researchers could do more analysis to further improve the crops and give tailor-made advise to farmers, on the use of fertilizer for example. Blockchain technologies (Ge et al., 2017) could further help certify the origins of soy seeds to growing plots, specialized production processes, and eventually specific target markets and brands. 


\section{Supplementary material}

Supplementary material can be found online at: https://doi.org/10.22434/IFAMR2019.0026

Table S1. Project earnings per project.

Table S2. Expenses per project for project organization and overhead.

\section{Acknowledgements}

The authors thank NWO Wotro for financial support. They also thank Sojagnon, particularly Patrice Sèwadé and Amonsou Biaou Fortuné, for participating in interviews. They thank Yuan Zhao for research assistance and Falylath Babah Daouda for translation during interviews. They thank Joseph Hounhouigan for reading the paper. All quotes were validated by the interviewees.

\section{References}

Adekambi, S.A., P.T. Ingenbleek and H.C. van Trijp. 2015. Integrating producers at the base of the pyramid with global markets: a market learning approach. Journal of International Marketing 23(4): 44-63.

Alliance for a Green Revolution in Africa (AGRA). 2017. Africa agriculture status report: the business of smallholder agriculture in sub-Saharan Africa. AGRA, Nairobi, Kenya.

Alliance Soja, 2013. Rapport du Forum autour des innovations sur le soja et le renforcement des liens entre les acteurs. Alliance Soja, Bohicon, Bénin.

Angie, Y.S., N.G. Billy and C.H. Hau. 2009. Nodulation of native woody legumes in Hong Kong, China. Plant Soil 316: 35-43.

Ayenan, M.A.T., P.L. Sèwadé and S.M. Agboton. 2017. Towards effective soybean seed systems in Benin: current situation and prospects for production and delivery of good quality seed. Journal of Crop Improvement 31(3): 379-399.

Bindraban, P.S., A.C. Franke, D.O. Ferraro, C.M. Ghersa, L.A.P. Lotz, A. Nepomuceno, M.J.M. Smulders and C.C.M. Van de Wiel. 2009. GM-related sustainability: agroecological impacts, risk and opportunities of soy production in Argentina and Brazil. Plant Research International Report 259. Plant Research International, Wageningen, the Netherlands. Available at: https://tinyurl.com/y3tfbj13

Chauvin, N.D., F. Mulangu and G. Porto. 2012. Food production and consumption trends in sub-Saharan Africa: prospects for the transformation of the agricultural sector. UNDP Regional Bureau for Africa, New York, NY, USA.

Dietz, T. 2016. Africa 2016-2100: population growth, urbanization and migration. Wageningen School of Social Sciences (WASS) seminar. November 16, 2016. WASS, Wageningen UR, Wageningen, the Netherlands.

Dogan, E., H. Kirnak and O. Copur. 2007. Deficit irrigations during soybean reproductive stages and CROPGRO-soybean simulations under semi-arid climatic conditions. Field Crop Research Journal 103: 154-159.

Food and Agriculture Organisation (FAO). 2013. The state of food and agriculture: food systems for better nutrition. Available at: http://www.fao.org/docrep/018/i3300e/i3300e00.htm

Food and Agriculture Organisation (FAO). 2014. Africa - glycine max - production (tons). Available at: https://fr.actualitix.com/pays/afri/afrique-soja-production.php

Food and Agriculture Organisation (FAO). 2017. Regional overview of food security and nutrition in Africa 2017. The food security and nutrition - conflict nexus: building resilience for food security, nutrition, and peace. FAO, Accra, Ghana.

Food and Agriculture Organisation (FAO) et Commission de la CEDEAO. 2018. Profil National Genre des Secteurs de L'Agriculture et du Développement Rural-Bénin. Série des Evaluations Genre des Pays. Cotonou, Benin, 148 pp.

Friedman, M. and D. Brandon. 2001. Nutritional and health benefits of soy proteins. Journal of Agricultural and Food Chemistry 49(3): 1069-1086. 
Ge, L., C. Brewster, J. Spek, A. Smeenk and J. Top, 2017. Blockchain for agriculture and food; findings from the pilot study. Report 2017-112. Wageningen Economic Research, Wageningen, the Netherlands, $34 \mathrm{pp}$.

Haskett, J.D., Y.A. Pachepsky and B. Acock. 2000. Effect of climate and atmospheric change on soybean water stress: a study of Iowa. Ecological Modelling 135(2-3): 265-277.

Herrero, M., P. Thornton, B. Power, J. Bogard, R. Remans, S. Fritz, J. Gerber, G. Nelson, L. See, K. Waha, R. Watson, P. West, L. Samberg, J. van de Steeg, E. Stephenson, M. van Wijk and P. Havlík. 2017. Farming and the geography of nutrient production for human use: a transdisciplinary analysis. Lancet Planet. Health 1(1): e33-e42.

Institut National de la Statistique et de l'Analyse Économique (INSAE). 2016. Statistiques économiques. Available at: https://www.insae-bj.org/statistiques/statistiques-economiques

Javaheri, F. and J.F. Baudoin. 2001. Le soja. Agriculture en Afrique tropical. Directorate General for International Cooperation, Ministry of Foreign Affairs, External Trade and International Cooperation, Brussels, Belgium, pp. 860-882.

Lowder, S.K., J. Skoet and T. Raney. 2016. The number, size, and distribution of farms, smallholder farms, and family farms worldwide. World Development 87: 16-29.

Minot, N. and L. Daniels. 2005. Impact of global cotton markets on rural poverty in Benin. Agricultural Economics 33: 453-466.

Ncube, M., C.L. Lufumba and K. Steve. 2011. The middle of the pyramid: dynamics of the middle class in Africa. Market Brief, 20 April 2011. African Development Bank, Abidjan, Côte d'Ivoire.

Proto, M., S. Supino and Malandrino, O. 2000. Cotton: a flow cycle to exploit. Industrial Crops and Products 11(2-3): 173-178.

Shurtleff, W. and A. Aoyagi. 2007. History of soybeans and soyfoods: 1100 BC to 1980s. Soyinfo Center, Lafayette, CA, USA.

Shurtleff, W. and A. Aoyagi. 2009. History of soybeans and soyfoods in Africa (1857-2009): extensively annotated bibliography and sourcebook. Soyinfo Center, Lafayette, CA, USA.

Sidi, A.T. 2012. Le leadership des acteurs sociaux au sein des organisations professionelles (OPA) au Bénin. Cas des OPA Soja dans la commune de Glazoué. Ecole Supérieure Internationale d'Enseignement Technique (ESIET), Bénin.

Sodjinou, E., P.Y. Adégbola and A.B. Bankolé. 2011. Analyse de la performance des chaînes de valeurs de l'ananas au Bénin. Programme Analyse de la Politique Agricole, Porto-Novo, Benin.

Tefera, H. 2011. Breeding for promiscuous soybeans at IITA, soybean-molecular aspects of breeding. IntechOpen, London, UK.

United Nations Department of Economic and Social Affairs (UNDESA). 2016. World economic situation prospects 2016 database. United Nations, New York, NY, USA.

United Nations Department of Economic and Social Affairs, Population Division. 2015. World population prospects: the 2015 revision. Key findings and advance tables. ESA/P/WP.241. United Nations, New York, NY, USA.

United Nations. 2014. World urbanization prospects: highlighs. United Nations, New York, NY, USA.

United Nations Economic Commission for Africa (ECA). 2017. Economic report on Africa 2017: urbanization and industrialization for Africa's transformation. United Nations Economic Commission for Africa, Addis Ababa, Ethiopia.

World Bank. 2017. World development indicators. World Bank, Washington, DC, USA. 